\title{
The Influence of Stock Plant Fertilization on Tissue Concentrations of N, P and Carbohydrates and the Rooting of Prosopis alba Cuttings
}

\author{
SONIA MARIA DE SOUZA and PETER FELKER \\ Caesar Kleberg Wildlife Research Institute, Texas A\&I University, Kingsville, TX (U.S.A.) \\ (Accepted 11 March 1986)
}

\section{ABSTRACT}

De Souza, S.M. and Felker, P., 1986. The influence of stock plant fertilization on tissue concentrations of N, P, and carbohydrates and the rooting of Prosopis alba cuttings. For. Ecol. Manage, 16: 181-190.

Clonal propagation techniques are required for Proposis due to great variability in biomass productivity, pod productivity, and nitrogen fixation from seed propagated stock. Previous studies identified a decline in the rooting percentage of cuttings taken from stock plants that were grown in the growth chamber and harvested every four weeks. To determine the influence of the mineral nutrient status of the stock plants on the rooting of cuttings, fertilized and nonfertilized Prosopis alba clone $\mathrm{B}_{2} \mathrm{~V}_{50}$ stock plants were established under $1000 \mathrm{~W}$ metal halide lamps in the greenhouse. A complete macro- and micronutrient solution was used. The regrowth was harvested after 4, 8 , 12,16 , and 20 weeks, and alternate nodes from each stem were taken for the rooting assay and for $\mathrm{N}, \mathrm{P}, \mathrm{K}, \mathrm{Ca}, \mathrm{Mg}, \mathrm{Fe}, \mathrm{Zn}$ and total available carbohydrate evaluation $(N=79)$. The mean rooting percentage for the five harvest cycles was $58 \%$ for the fertilized stock plants, and $44 \%$ for the nonfertilized stock plants $(P=0.087)$. There was no significant correlation between rooting percentage and leaf carbohydrate $(P=0.964)$, stem carbohydrate $(P=0.876)$ and leaf plus stem phosphorus $(P=0.319)$. The nonsignificant correlation between percent rooting and carbohydrates was negative $(r=-0.018)$. However, there was a significant correlation with stem nitrogen and percent rooting $(P=0.009)$ and an inverse correlation between stem nitrogen and leaf carbohydrate content $(r=-0.353, P=0.001)$. This suggests that unbalanced fertilizers, rich in nitrogen and low in $\mathrm{P}, \mathrm{K}$, and other nutrients, might stimulate stem $\mathrm{N}$ and be successful in maintaining high rooting percentages from stock plants.

\section{INTRODUCTION}

Nitrogen fixing trees of the genus Prosopis are drought resistant and well adapted to poor soils of dry regions (National Academy of Sciences, 1979). In addition to producing biomass for use as a fuel, the trees provide pods which can be used for human or livestock food and they are useful for soil and environmental amelioration in general. 
Previous research encountered large variability in Prosopis in mean biomass productivity per tree between species ( $0.2-29 \mathrm{~kg}$ per tree) and within species (1.9-23.9 kg per tree) (Felker et al., 1983). Considerable variation was also exhibited in tolerance to cold, salinity, and in pod production (Felker et al., $1981,1982,1984)$. This variability can be attributed to the fact that several Prosopis species are self-incompatible (Simpson, 1977) and thus the plants are obligate outcrossers that do not propagate true to type from seed.

Rooting of Prosopis cuttings has been previously reported by Leakey and Last (1980), Felker and Clark (1981), and De Souza and Nascimento (1984). The latter two groups reported strong seasonal influences on the rooting of cuttings. The influences of environmental parameters on rooting of cuttings were examined in growth chamber studies by Klass (1984) and Klass et al. (1985). These workers found that a temperature of $35^{\circ} \mathrm{C}$, a light intensity of $520 \mu \mathrm{E} \mathrm{m}^{-2} \mathrm{~s}^{-1}$, and a $12 \mathrm{~h}$ photoperiod were necessary for optimum rooting of $P$. alba clone $\mathrm{B}_{2} \mathrm{~V}_{50}$.

An unexpected result of the experiment to determine the optimum environmental parameters for rooting was a significant decline in all rooting parameters as the one year old, previously uncut stock plants were harvested every 3-4 weeks for rooting material (Klass et al., 1985). Suggested causes for this decline included: decreased juvenility of the stock plants, inadequate mineral nutrient status of the stock plants due to overharvest, and decreased supply of carbohydrate in the stem and root system of the stock plant.

This study was conducted to determine (1) if fertilization could overcome the decline in rooting percentages associated with successive harvests of stock plants for rooting material and (2) the correlations between rooting percentages and macronutrients, micronutrients, and carbohydrates in the leaves and stems of the stock plants.

\section{MATERIALS AND METHODS}

Prosopis alba clone $\mathrm{B}_{2} \mathrm{~V}_{50}$ (referred to as $\mathrm{V}_{50} \mathrm{~B}_{2}$ in Felker et al., 1983) used in this experiment was selected in a progeny trial to screen for biomass productivity under heat/drought stress in the California Imperial Valley (Felker et al., 1983). The parent accession of this clone was P. alba 0194 that was collected from ornamental trees growing along the Colorado River in Big River, California. These South American trees were introduced into southern California or southern Arizona by unknown means in the early 1950's.

To determine the influence of the mineral nutrient status of the stock plants on the rooting of cuttings, fertilized and nonfertilized stock plants were established in the greenhouse. The fertilized plants received one liter of a complete macro- and micronutrient solution three times a week. The nonfertilized stock plants received no fertilizer addition. A commercial fertilizer formulation (ValGro ) was diluted to the following composition: nitrogen ( $800 \mathrm{mg} / \mathrm{l})$, phospho- 
rus $(500 \mathrm{mg} / \mathrm{l})$ potassium $(300 \mathrm{mg} / \mathrm{l})$, zinc $(2 \mathrm{mg} / \mathrm{l})$, iron $(0.2 \mathrm{mg} / \mathrm{l})$, magnesium $(0.15 \mathrm{mg} / \mathrm{l})$, copper and manganese $(5 \mathrm{mg} / \mathrm{l})$. The plants and vegative regrowth were sprayed once a week with the fungicide benomyl [methyl-1(butyl-carbamoyl)-2-benzimidazole carbamate ].

Previous studies established the need for a light intensity of at least $200 \mu \mathrm{E}$ $\mathrm{m}^{-2} \mathrm{~s}^{-1}$ for the stock plants (Klass, 1984; Klass et al., 1985). Since these experiments were partially conducted in the winter when light intensities in the greenhouse were as low as $100 \mu \mathrm{E} \mathrm{m}^{-2} \mathrm{~s}^{-1}, 1000 \mathrm{~W}$ metal halide lamps were used to supplement the light intensity to a minimum of $300 \mu \mathrm{E} \mathrm{m}^{-2} \mathrm{~s}^{-1}$. Two nonfertilized and two fertilized stock plants were established under each of four metal halide lamps. Thus a randomized complete block design was used with each light source as a block.

The $2.5 \mathrm{~m}$ tall stock plants, in $20 \mathrm{l}$ pots, were about one year old and had a basal diameter of about $3 \mathrm{~cm}$. Before the experiment, the stock plants were cut at about $1 \mathrm{~m}$ in height leaving a severed stem about $2 \mathrm{~cm}$ in diameter.

The stock plant regrowth was successively harvested after $4,8,12,16$, and 20 weeks. The fertilized stock plants typically produced 5 to 10 new shoots about $60-80 \mathrm{~cm}$ long in the $3-4$ week period, while the nonfertilized plants produced 2-3 shoots $30-40 \mathrm{~cm}$ long. At each harvest alternating nodes from each stem were taken for chemical analysis and the rooting assay. The leaves and stems were analyzed separately for $\mathrm{N}, \mathrm{K}, \mathrm{Ca}, \mathrm{Mg}, \mathrm{Fe}, \mathrm{Zn}$, and total available carbohydrate, but were pooled for the phosphorus analyses. From each of the eight fertilized and eight nonfertilized stock plants, 16 cuttings were taken for the rooting assay and two samples (leaf and stem) for chemical analyses.

The cuttings had two nodes with the leaves removed from the lower node. Each cutting was dipped in $0.3 \%$ IBA in talcum, then placed in a round plastic pot $(13 \times 13 \mathrm{~cm})$ filled with fine vermiculite previously soaked for two days. Each pot plus vermiculite received $80 \mathrm{ml}$ of a $0.5 \mathrm{~g} / \mathrm{l}$ drench of the fungicide Banrot [5-ethoxy-3-trichloromethyl-1,2,4-thiadiazole and dimethyl-4,4-O,Ophenylenebis(thioallophanate) ]. Eight cuttings were planted per pot, then placed in a polyethylene bag $(25 \times 41 \mathrm{~cm})$, sprayed with benomyl + captan $(0.5$ $\mathrm{g} \mathrm{l}^{-1}$ ) and the top sealed with rubber band. The cuttings were placed in a light bank with a $12 \mathrm{~h}$ photoperiod and $300 \mu \mathrm{E} \mathrm{m}^{-2} \mathrm{~s}^{-1}$ of fluorescent light. Three weeks after placement under the light bank, the rooting percentage, the number of roots per cutting, and the length of the longest root were measured.

Samples for $\mathrm{N}$ and total available carbohydrate evaluation were dried for 36 $\mathrm{h}$ at $70^{\circ} \mathrm{C}$, while samples for $\mathrm{P}, \mathrm{K}, \mathrm{Ca}, \mathrm{Mg}, \mathrm{Fe}$, and $\mathrm{Zn}$ were dried for $24 \mathrm{~h}$ at $70^{\circ} \mathrm{C}$. The dried samples were ground to pass through a 40 -mesh screen using a Wiley mill equipped with stainless steel hardware. Tissue $\mathrm{N}$ was measured using a micro-Kjeldahl digestion, followed by colorimetric determination of the ammonium as described elsewhere in this volume (Cline et al., 1986). A concentrated nitric acid digestion was used for the remainder of the elements, also as described by Cline et al. (1986). Phosphorus was measured by the col- 

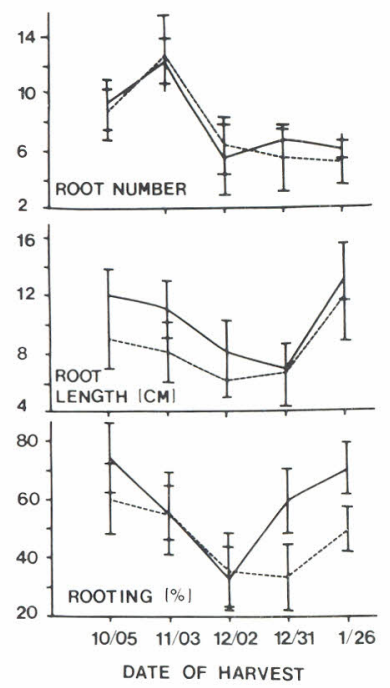

Fig. 1. The number of roots per cutting, maximum root length, and rooting percentage of $P$. alba $\mathrm{B}_{2} \mathrm{~V}_{50}$ cuttings. Broken line: nonfertilized stock plant, solid line: fertilized stock plant. The vertical lines represent $95 \%$ confidence intervals for the means.

orimetric procedure of Murphy and Riley (1962) and the remaining elements were measured using atomic absorption spectrophotometry. To evaluate the effect of $\mathrm{K}, \mathrm{Ca}, \mathrm{Mg}, \mathrm{Fe}$ and $\mathrm{Zn}$ on rooting, 24 samples (leaf plus stem) were selected that represented the full range in rooting percentage.

The total available carbohydrates were extracted according to Smith et al. (1964), and measured spectrophotometrically using the anthrone reagent (Yemm and Willis, 1954).

\section{RESULTS}

The effect of stock plant fertilization on the number of roots per cutting, maximum root length, and rooting percentage is presented in Fig. 1. Each data point is the mean of eight plants, two pots per plant with eight cuttings per pot. The vertical lines represent the $95 \%$ confidence interval for the means ( $\mathrm{T}$-test). A decline in rooting percentage was observed on the third harvest. The rooting percentage started off higher $(73 \%)$ for the fertilized than for the nonfertilized stock plants $(60 \%)$, but they declined to $33 \%$ and $35 \%$ respectively for the third harvest. These mean rooting percentages were not statistically different except in the fourth and fifth harvest, where the rooting percentage for the fertilized stock plants was higher than for nonfertilized plants.

The maximum root length of the cuttings from the fertilized stock plants decreased from $12.1 \mathrm{~cm}$ (first harvest) to $7.2 \mathrm{~cm}$ (fourth harvest), and increased 


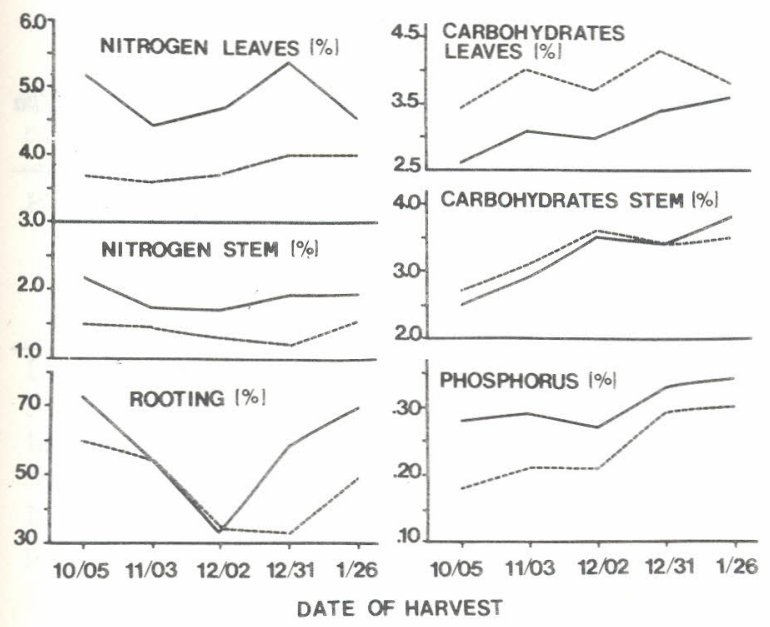

Fig. 2. Rooting percentage of cuttings, nitrogen, carbohydrate and phosphorus contents for the fertilized and nonfertilized $P$. alba $\mathrm{B}_{2} \mathrm{~V}_{50}$ stock plants. Broken line: nonfertilized stock plant. Solid line: fertilized stock plant.

again to $13.3 \mathrm{~cm}$ at the last harvest. A similar response was obtained from the nonfertilized stock plants. The number of roots in both treatments also dereased at the third harvest, but further remained constant until the last observation. As can be seen in Fig. 1, the 95\% confidence intervals for the root number and root length overlapped for all harvest periods.

There was a wide variation in rooting between clonal stock plants of the same treatment. For example, the rooting percentage of the eight fertilized stock plants ranged from $38 \%$ to $100 \%, 25 \%$ to $75 \%, 0 \%$ to $63 \%, 13 \%$ to $88 \%$ and $38 \%$ to $88 \%$ for the first, second, third, fourth, and fifth harvests, respectively.

A comparison of the rooting percentage with the nitrogen, carbohydrate, and phosphorus contents of the leaves and stems is presented in Fig. 2. The nitrogen contents of the fertilized leaves and stems are high, i.e. equivalent to $31 \%$ and $12 \%$ crude protein, respectively. The nitrogen and phosphorus contents of the stems and leaves from the fertilized stock plants are greater than the nonfertilized stock plants. In contrast, the leaf and stem carbohydrate contents are higher for the nonfertilized stock plants. The strong dip in the rooting percentage at the third harvest is paralleled by a dip in phosphorus percentage and in increase in stem carbohydrate. The changes in the stem nitrogen content are not as large as the other parameters, but the stem $\mathrm{N}$ appears to track the rooting percentage for both the fertilized and nonfertilized stock plants better than any of the other parameters.

The statistical analysis for the influence of stock plant fertilization on rooting parameters and chemical composition of $P$. alba cuttings is presented in Table 1. When averaged over all five harvests, the rooting percentage for the 
TABLE 1

Effect of stock plant fertilization on percent rooting and chemical composition of Prosopis alba $\mathrm{B}_{2} \mathrm{~V}_{50}$ cuttings for all five harvest periods combined

\begin{tabular}{lccl}
\hline Plant characteristics & \multicolumn{3}{l}{ Mean of all time periods ${ }^{\mathrm{a}}$} \\
\cline { 2 - 4 } & Fertilized & $\begin{array}{l}\text { Non- } \\
\text { fertilized }\end{array}$ & $\begin{array}{l}\text { Level of } \\
\text { significance }\end{array}$ \\
\hline Root number & 7.90 & 7.60 & \\
Root length (cm) & 10.30 & 8.48 & \\
Rooting (\%) & 58.00 & 44.00 & 0.0866 \\
Leaf N (\%) & 4.85 & 3.79 & 0.0031 \\
Stem N (\%) & 1.88 & 1.40 & 0.0033 \\
Leaf carbohydrate (\%) & 3.15 & 3.77 & 0.0222 \\
Stem carbohydrate (\%) & 3.21 & 3.26 & 0.8595 \\
Leaf + stem P (\%) & 0.30 & 0.23 & 0.0940 \\
\hline
\end{tabular}

${ }^{a}$ Each entry is the mean of 5 replications in time, consisting of 40 observations for fertilized and 39 for nonfertilized.

cuttings from the fertilized stock plants was greater $(P=0.087)$ than for the nonfertilized stock plants. The greater leaf and stem $\mathrm{N}$ in the fertilized stock plants were very highly significant ( $P=0.003$ in both cases). Leaf carbohydrate was significantly greater for the nonfertilized stock plants $(P=0.022)$, but stem carbohydrate $(P=0.859)$ and leaf plus stem $\mathrm{P}(P=0.94)$ were not significantly different between treatments.

The correlation between rooting percentage and leaf and tissue concentrations of $\mathrm{N}$, carbohydrate and $\mathrm{P}$ presented in Table 2 support the hypothesis that stem $\mathrm{N}$ tracks the percent rooting better than the other parameters. For example, no significant correlation was detected between rooting percentage

\section{TABLE 2}

Correlation coefficients of rooting percent with $\mathrm{N}$, carbohydrates, and $\mathrm{P}$ content of $P$. alba $\mathrm{B}_{2} \mathrm{~V}_{50}$ cuttings $^{\mathrm{a}}$

\begin{tabular}{lcl}
\hline Plant characteristics & \multicolumn{2}{l}{ Rooting percentage } \\
\cline { 2 - 3 } & $\begin{array}{l}\text { Correlation } \\
\text { coefficient }\end{array}$ & $\begin{array}{l}\text { Level of } \\
\text { significance }\end{array}$ \\
\hline Leaf nitrogen & 0.205 & 0.0702 \\
Stem nitrogen & 0.368 & 0.0009 \\
Leaf carbohydrates & -0.005 & 0.9639 \\
Stem carbohydrates & -0.018 & 0.8757 \\
Leaf + stem phosphorus & 0.114 & 0.3191 \\
\hline
\end{tabular}

${ }^{a}$ For 79 pairs of observation, chemical analyses versus rooting $(\%)$. 


\section{TABLE 3}

Correlation coefficients of nitrogen with carbohydrate and phosphorus contents of $P$. alba $\mathrm{B}_{2} \mathrm{~V}_{50}$ cuttings $^{\mathrm{a}}$

\begin{tabular}{|c|c|c|c|c|}
\hline \multirow[t]{2}{*}{ Plant characteristics } & \multicolumn{2}{|c|}{ Leaf nitrogen } & \multicolumn{2}{|c|}{ Stem nitrogen } \\
\hline & $\begin{array}{l}\text { Corr. } \\
\text { coeff. }\end{array}$ & $\begin{array}{l}\text { Level } \\
\text { of sign. }\end{array}$ & $\begin{array}{l}\text { Corr. } \\
\text { coeff. }\end{array}$ & $\begin{array}{l}\text { Level } \\
\text { of sign. }\end{array}$ \\
\hline Leaf nitrogen & - & - & 0.508 & 0.0001 \\
\hline Stem nitrogen & 0.508 & 0.0001 & - & - \\
\hline Leaf carbohydrates & -0.344 & 0.0019 & -0.353 & 0.0014 \\
\hline Stem carbohydrates & -0.010 & 0.9312 & -0.167 & 0.1416 \\
\hline $\begin{array}{l}\text { Leaf+stem } \\
\text { phosphorus }\end{array}$ & 0.356 & 0.0013 & 0.355 & 0.0013 \\
\hline
\end{tabular}

${ }^{a}$ For 79 pairs of observation.

and leaf or stem carbohydrate or phosphorus concentrations. Leaf $\mathrm{N}$ was slightly correlated $(r=0.205, P=0.070)$ with rooting percentage while stem $\mathrm{N}$ was highly correlated ( $r=0.368, P=0.0009$ ). Since stem $\mathrm{N}$ was so significantly correlated with rooting percentage, correlations between stem $\mathrm{N}$ and the other leaf and stem parameters were examined (Table 3 ). Stem nitrogen was significantly negatively correlated $(r=-0.353, P=0.001)$ with leaf carbohydrate, but not with stem carbohydrate. In contrast, leaf plus stem phosphorus was significantly and positively correlated $(r=0.355, P=0.001)$ with stem nitrogen.

The correlations between $\mathrm{K}, \mathrm{Ca}, \mathrm{Mg}, \mathrm{Fe}, \mathrm{Zn}$ and rooting percentage and $\mathrm{N}$ are presented in Table 4 . No significant correlations were detected between $\mathrm{K}$, $\mathrm{Ca}, \mathrm{Mg}, \mathrm{Fe}$, or $\mathrm{Zn}$ and rooting percentage. However, Leaf $\mathrm{N}$ was correlated with

\section{TABLE 4}

Correlation coefficients between percent rooting, tissue $\mathrm{N}$, and $\mathrm{K}, \mathrm{Ca}, \mathrm{Mg}, \mathrm{Fe}, \mathrm{Zn}$ concentrations of $P$. alba $\mathrm{B}_{2} \mathrm{~V}_{50}$ cuttings $^{\mathrm{a}}$

\begin{tabular}{|c|c|c|c|c|c|c|}
\hline \multirow[t]{3}{*}{ Leaf nutrient } & \multicolumn{2}{|c|}{ Percent rooting } & \multicolumn{4}{|c|}{ Nitrogen } \\
\hline & \multirow{2}{*}{$\begin{array}{l}\text { Corr. } \\
\text { coeff. }\end{array}$} & \multirow{2}{*}{$\begin{array}{l}\text { Level } \\
\text { of sign. }\end{array}$} & \multicolumn{2}{|l|}{ Leaf } & \multicolumn{2}{|l|}{ Stem } \\
\hline & & & $\begin{array}{l}\text { Corr. } \\
\text { coeff. }\end{array}$ & $\begin{array}{l}\text { Level } \\
\text { of sign. }\end{array}$ & $\begin{array}{l}\text { Corr. } \\
\text { coeff. }\end{array}$ & $\begin{array}{l}\text { Level } \\
\text { of sign. }\end{array}$ \\
\hline Potassium & 0.071 & $\mathrm{~ns}$ & 0.004 & $\mathrm{~ns}$ & 0.117 & $\mathrm{~ns}$ \\
\hline Calcium & -0.053 & $\mathrm{~ns}$ & 0.220 & $\mathrm{~ns}$ & 0.090 & ns \\
\hline Magnesium & 0.085 & ns & 0.525 & 0.05 & 0.520 & 0.05 \\
\hline Iron & -0.360 & ns & 0.286 & $\mathrm{~ns}$ & -0.182 & ns \\
\hline Zinc & 0.084 & $\mathrm{~ns}$ & 0.460 & 0.05 & 0.218 & $\mathrm{~ns}$ \\
\hline
\end{tabular}

${ }^{\text {aF }}$ or 24 pairs of observation, chemical analyses versus rooting $(\%)$. ns: $P$-value below 0.20 . 
$\mathrm{Mg}(r=0.525, P=0.05)$ and $\mathrm{Zn}(r=0.460, P=0.05)$. Stem $\mathrm{N}$ was only correlated with $\mathrm{Mg}(r=0.520, P=0.05)$.

\section{DISCUSSION}

Through use of fertilization, $70 \%$ rooting was achieved at fifth harvest, while $59 \%$ was obtained when no fertilizer was used. In spite of an unexplained decrease in rooting observed at the third harvest, the mean for all five harvests was $58 \%$ rooting for the fertilized stock plants and $44 \%$ for the nonfertilized ones.

The $58 \%$ mean rooting for all five periods is considerably less than the $83 \%$ mean for the $12 \mathrm{~h}$ stock plant/12 h cutting photoperiod observed by Klass (1984) and Klass et al. (1985) in growth chamber studies. The lower percentage rooting in the.present study is, no doubt, partially due to less control of environmental parameters in the greenhouse as compared to the growth chambers. Nevertheless, the $58 \%$ rooting in the greenhouse in the winter is a considerable improvement over the $15 \%$ rooting previously found by Felker and Clark (1981) in the greenhouse during the winter.

Despite the fact that the fertilization did not greatly enhance the rooting percentage, the nonfertilized stock plants grew very slowly compared to the fertilized stock plants, making it difficult to obtain sufficient cutting material for the experiments. Thus, frequent fertilization will be required to maintain the growth rates required for commercial production.

Carbohydrate reserves in the leaves and stems of cuttings has long been considered an important determinant for rooting success (Hess, 1969; Eliasson, 1978; Hartmann and Kester, 1983), and the fact that we observed no correlation between leaf and stem carbohydrate with rooting percentage was surprising. It is curious that this clone has such an obligate requirement for high light intensities (Klass et al., 1985) and yet has such a poor correlation between total available carbohydrate and rooting percentage. De Souza and Nascimento (1984) have demonstrated that pruning Prosopis leaves prior to incubating them for rooting greatly decreases the rooting percentage.

These Prosopis leaves and stems were considerably higher in crude protein ( $31 \%$ and $12 \%$, respectively) than other nonlegume hardwood species and it is possible that legume cuttings have a greater demand for nitrogen than for carbohydrate. Production of new leaves during rooting may represent a significant $\mathrm{N}$ sink. Alternatively, these high $\mathrm{N}$ contents may serve as a protein source during root production. The fact the De Souza and Nascimento (1984) have demonstrated an obligate requirement for leaves, coupled with the high leaf crude protein, suggests a strong demand for nitrogen in the cuttings.

The high leaf carbohydrate observed in cuttings obtained from the nonfertilized stock plants may be due to the reduced growth associated with limiting nutrients. On the other hand, the fertilized stock plants are less nutrient lim- 
ited and are capable of more rapid growth, thus diluting the carbohydrate concentration in the leaves and stems.

Since $\mathrm{N}$ was positively correlated with rooting percentage and negatively correlated with leaf carbohydrate, this indicates that unbalanced fertilizers, rich in $\mathrm{N}$ and low in other nutrients, might increase stem $\mathrm{N}$, decrease stem carbohydrate, and be successful in maintaining high rooting percentages from stock plants.

Although $\mathrm{P}, \mathrm{Mg}$ and $\mathrm{Zn}$ were not correlated with rooting percentage, they were correlated with $\mathrm{N}$ content, suggesting a need to understand the relationship between these elements with nitrogen and possible effects on rooting.

The wide variation in rooting percentage from replicated clonal stock plants in the same treatment, at the same time period i.e. from $38 \%$ to $100 \%$ at the first harvest and from $0 \%$ to $63 \%$ at the depressed third harvest, implies lack of control of an additional rooting factor. Furthermore, the third harvest period had a low rooting percentage for both the fertilized and nonfertilized stock plants for no apparent reason. There were no mechanical failures and the environmental records indicated no unusual events. Thus, there still are major unknown factors besides exogenously supplied auxin concentrations, air temperature, light regimes, and nutrient requirements that dramatically influence rooting percentages and routinely preclude obtaining near $100 \%$ rooting success.

\section{ACKNOWLEDGEMENTS}

The financial assistance of the U.S. Department of Energy subcontract number 9066, The Caesar Kleberg Wildlife Research Institute, and the Brazilian Agricultural Research Organization (EMBRAPA) is gratefully acknowledged.

\section{REFERENCES}

Cline, G., Rhodes, D. and Felker, P., 1986. Micronutrient, phosphorus, and $\mathrm{pH}$ influences on growth and leaf tissue levels of Prosopis alba and Prosopis glandulosa. In: P. Felker (Editor), Establishment and productivity of tree plantings in semiarid regions. For. Ecol. Manage., 16: 81-93.

De Souza, S.M. and Nascimento, C.E. de S., 1984. Propagacao vegetativa de Algaroba atraves de estaquia (Vegetative propagation of algaroba by cuttings). EMBRAPA/CPATSA, Pesquisa em Andamento, 27: 1-3 (in Portugese).

Eliasson, L., 1978. Effects of nutrients and light on growth and root formation in Pisum sativum cuttings. Physiol. Plant., 43: 13-18.

Felker, P. and Clark, P.R., 1981. Rooting of mesquite (Prosopis) cuttings. J. Range Manage., 34: 446-468.

Felker, P., Clark, P.R., Laag, E.A. and Pratt, F.P., 1981. Salinity tolerance of the tree legumes mesquite (Prosopis glandulosa var torreyana, $P$. velutina and $P$. articulata), algarrobo ( $P$. 
chilensis), kiawe ( $P$. pallida), and tamarugo ( $P$. tamarugo) grown in sand culture on nitrogen free media. Plant Soil, 61: 311-317.

Felker, P., Clark, P.R., Nash, P., Osborn, J.F. and Cannel, G.H., 1982. Screening Prosopis (mesquite) for cold tolerance. For. Sci., 28: 256-262.

Felker, P., Cannell, G.H., Clark, P.R., Osborn, J.F. and Nash, P., 1983. Biomass production of Prosopis species (mesquite), Leucaena, and other leguminous trees grown under heat/drought stress. For. Sci., 29: 529-606.

Felker, P., Clark, P.R., Osborn, J.F. and Cannell, G.H., 1984. Prosopis pod production - comparison of North American, South American, Hawaiian, and African germplasm in young plantations. Econ. Bot., 38: 36-51.

Hartmann, T.H. and Kester, E.D., 1983. Anatomical and physiological basis of propagation by cuttings. In: Plant Propagation. Prentice-Hall, Englewood Cliffs, NJ, pp. 235-297.

Hess, E.C., 1969. Internal and external factors regulating root initiation. In: W.J. Whillington (Editor), Root Growth. Cloves and Sons, London, pp. 42-53.

Klass, S.D., 1984. The influence of environmental factors and growth regulators on the rooting of mesquite (Prosopis alba) cuttings. Texas A \& I University. M.S. Thesis, 68 pp.

Klass, S.D., Bingham, R.L., Finker-Templemen, L. and Felker, P., 1985. Optimizing the environment for rooting cuttings of productive clones of Prosopis alba (mesquite/algarrobo). J. Hortic. Sci., 60: 275-284.

Leakey, R.R.B. and Last, F.T., 1980. Biology and potential of Prosopis species in arid environments, with particular to $P$. cineraria. J. Arid Environm., 3: 9-24.

Murphy, J. and Riley, J.P., 1962. A modified single solution method for determination of phosphate in natural waters. Anal. Chim. Acta., 27: 31-36.

National Academy of Sciences, Washington, DC, 1979. Prosopis species. In: Tropical legumes: resources for the future; report. Washington, DC. pp. 153-163.

Simpson, B.B., 1977. Breeding systems of dominant perennial plants of two disjunct warm desert ecosystems. Oecologia, 27: 203-226.

Smith, D., Paulsen, G.M. and Raguse, C.A., 1964. Extraction of total available carbohydrates from grass and legume tissue. Plant Physiol., 39: 960-962.

Yemm, E.W. and Willis, A.J., 1954. The estimation of carbohydrates in plant extracts by anthrone. Biochemistry, 57: 508-514. 